\title{
Experience in applying lean production concepts in the service sector
}

\author{
Evgeniya Dyrina $^{1, a}$, Nadezhda Gavrikova ${ }^{1}$ \\ ${ }^{1}$ Tomsk Polytechnic University, 634050 Lenin Avenue, 30, Tomsk, Russia
}

\begin{abstract}
This article describes the experience of implementing lean production tools in the company services. The authors have based the research of the chef's work, built Ishikawa's diagram on one of the most important problems of the company and proposed the cyclogram of cooks at work. Problems were identified using this technology after analyzing domestic and foreign experience in implementing lean production. The algorithm for implementing lean production and the necessary tools for achievement of the goals of the enterprise were authored on the basis of experience gained analyses of theoretical materials, which were tested on the basis of the small business «White Dragon».
\end{abstract}

\section{Introduction}

Increasingly, top officials of the state are talking about the need to change the business model of production, reducing costs and increasing productivity in the time when the crisis is vital. It is possible to achieve such purposes using the concept of lean production. The term «lean production» was introduced into scientific circulation by John Krafchik in his work «The car that changed the world», released in 1990. [1]

Currently, we can formulate a definition of lean production based on the opinions of domestic and foreign experts. This formulation describes it as a modern concept of industrial management of the products value, the reduction of different types of losses (muda) through the introduction of a new production and management technologies, stable improvement of main and auxiliary processes. This approach provides the long-term competitiveness of the organization. Those Dennis defines waste with the Japanese word «muda», the opposite of value, which is simply what a customer is willing to pay. It is also common to see the definition of seven wastes that the lean philosophy seeks to eliminate: a) overproduction, the largest source of waste; b) waiting time, refers to materials that are waiting in queues to be processed; c) unnecessary transportation that does not generate added value to the product; d) unnecessary processing, some operations of a process could not exist; e) inventories, their reduction will occur through their root cause; f) motion; g) defects, producing defective products means waste materials; h) manpower, handling of defective materials and others. [2] Recently a new (eighth) waste has been introduced: the misuse of intellectual capital Womack and Jones. This waste means not stimulate or use the complete employee capacity in identify opportunities for improvement. [3]

The concept of lean production first was used only in the industry, but after some time the approach was adapted to the conditions of the service sector. Nowadays, large enterprises, small businesses, service and financial organizations,

\footnotetext{
${ }^{a}$ Corresponding author: zhenya_9309_93@mail.ru
} 
etc. can be found among the companies applying lean production.

Lately, Bowen and Youngdahl proposed a framework that depicts the convergence of manufacturing production to services (Figure 1). [4] Levitt was one of the first authors to study the transfer of organization principles applied to production lines for manufacturing systems towards services. His studies were based on the fact that the services sector could benefit from the techniques developed by manufacture. [5]

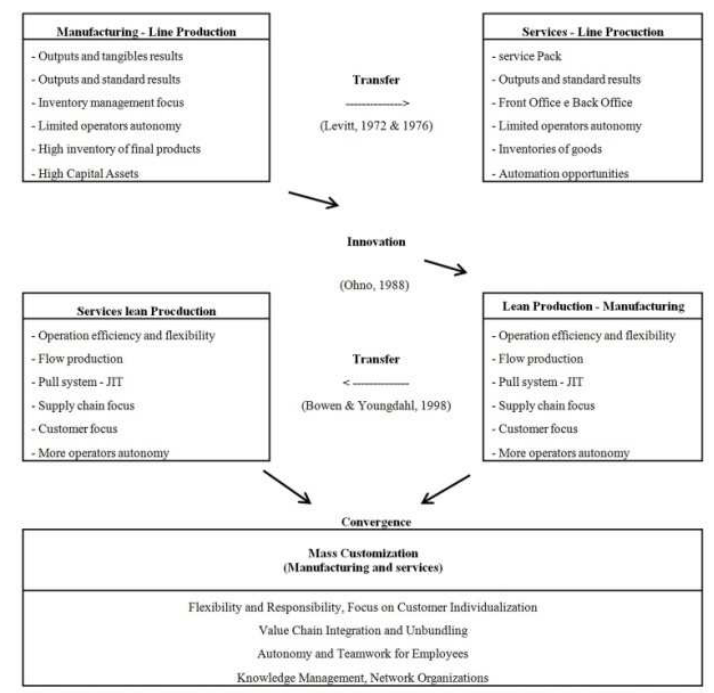

Fig. 1. The Convergence of services and guidelines of manufacturing production.

Based on the studies of Levitt and additionally taking advantage of the emergence of the fundamentals of lean production, researchers Bowen and Youngdahl were the first to carry out studies about the transfer of the lean production techniques used in industries to the services sector. They conducted case studies of applications of lean tools and published the results of what became known as a lean service. This study presented the characteristics of the lean service applied in a network of fast food restaurants, in a hospital and an airline company:

- Reduce the performance of trade-offs.

- Make the value-added processes flow and implement the customer-driven system.

- Eliminate losses in the value chain of activities, from development to delivery.

- Increase the customer focus and involvement in the development and delivery processes.

- Empower employees and teams. [4,5]

\section{Employment of technology}

Let us consider the application of lean production by the example of the small business «White Dragon». This business has been existing on the market since 2014. It is a relatively young company that delivers ready meals. The "White Dragon" owner performs two roles on his own: an owner and a cook. We have studied the production process in this company namely the preparation of sushi and rolls.

The purpose of the study was to identify losses in the company's food preparation processes. The following tasks were set for the execution of the goals:

- To analyze the time-study of the cooks' work;

- To build Ishikawa's diagrams for one of the problems identified.

- To define the tools for further optimization of the «bottlenecks» work.

The time-study was held on every weekend from January 31 to February 8 . All the actions of the chef were recorded during this period. They were distributed by type of time, after the calculation of the proportion of each type (in percentage) of costs to the time-study of the total time (table 1).

Table 1. Time spending structure

\begin{tabular}{|l|l|l|}
\hline & The structure of time & \multicolumn{1}{|c|}{$\mathbf{3 1 . 0 1 - 0 8 . 0 2 . 1 5}$} \\
\hline 1 & $\begin{array}{l}\text { Final-cleaning } \\
\text { preparations }\end{array}$ & $16: 42: 08(35,2 \%)$ \\
\hline 2 & $\begin{array}{l}\text { Search for the necessary } \\
\text { preparations }\end{array}$ & $4: 28: 31(9,4 \%)$ \\
\hline 3 & The loss of time & $2: 11: 57(4,6 \%)$ \\
\hline 4 & Preparation of the order & $11: 36: 14(24,5 \%)$ \\
\hline 5 & Registration of the order & $3: 02: 46(6,4 \%)$ \\
\hline 6 & Excess movement/action & $5: 17: 58(11,1 \%)$ \\
\hline L & Lunch & $4: 07: 22(8,7 \%)$ \\
\hline & Total & $\begin{array}{l}\mathbf{4 7 : 2 5 : 5 6} \\
(\mathbf{1 0 0 , 0 0 \% )}\end{array}$ \\
\hline
\end{tabular}

After we have analysed the process in order to streamline the process. As a result, we identified valuable (V) and not valuable $(\mathrm{N})$ actions for the consumer. It was revealed on the basis of the total time of 47 hours 25 minutes 56 seconds or about 2846 minutes: 
1. Actions, which are of value for the customer - 879 minutes (30.9\%);

2. Actions that do not have values:

(a) the subsidiary work or regulated time is the time spent for execution of works defined in the job description. They are not valuable for the buyer, but they provide valuable actions (muda 1 kind) - 1002 minute (35.2\%);

(b) losses (muda 2 kind) - 965 minutes $(33.9 \%)$.

After spending the timing identified several losses in workflows. To analyse the structure of the problem, for example, was based on the problem of a constant lack of blanks for sushi, which resulted in most of the time, when the order to splurge on cutting the ingredients (Figure 2).

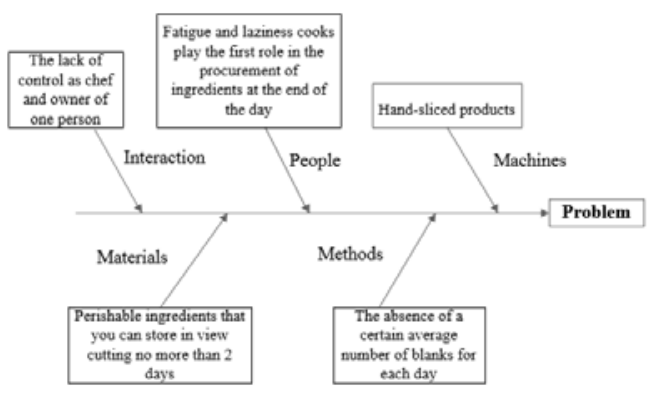

Fig. 2. Ishikawa Diagram

To solve the problem were asked to produce billets in set flexible working hours of the company, when the frequency of orders is small. On the basis of statistical observation it was revealed that the main stream of orders from customers occurs in SBU's previous declassification efforts and at lunch time (from 12 to 15 ) and in the evening (from 17 to 21 ). The rest of the time, namely, from 11 to 12 and from 15 to 17 , cook is free from work. To control employee mission, a trial version was developed (table 2), which can be enforceable.

Table 2. Cyclogramma action cooks

\begin{tabular}{|c|l|}
\hline Time & \multicolumn{1}{|c|}{ Type of work } \\
\hline $10.30-11.00$ & $\begin{array}{l}\text { Work preparation (cleaning racks, } \\
\text { display workplace cooks containers } \\
\text { with sesame, tuna flakes, etc.) }\end{array}$ \\
\hline $11.00-12.00$ & Cleaning shrimp and mussels \\
\hline $12.00-13.00$ & Execution of customer orders \\
\hline $13.00-14.00$ & Execution of customer orders \\
\hline $14.00-15.00$ & $\begin{array}{l}\text { Execution of customer orders / Dish } \\
\text { washing }\end{array}$ \\
\hline
\end{tabular}

\begin{tabular}{|l|l|}
\hline $15.00-15.30$ & $\begin{array}{l}\text { Preparation of sauces (spicy, sauce lava, } \\
\text { etc.) }\end{array}$ \\
\hline $15.30-16.00$ & Frying sesame \\
\hline $16.00-17.00$ & Cleaning salmon \\
\hline $17.00-18.00$ & Execution of customer orders \\
\hline $18.00-19.00$ & Execution of customer orders \\
\hline $19.00-20.00$ & Execution of customer orders \\
\hline $20.00-21.00$ & $\begin{array}{l}\text { Execution of customer orders / Dish } \\
\text { washing }\end{array}$ \\
\hline $21.00-22.00$ & $\begin{array}{l}\text { Preparation of rice for the next working } \\
\text { day (cooking, add vinegar, etc.) }\end{array}$ \\
\hline $22.00-23.00$ & Free time / Cleaning and the workplace \\
\hline
\end{tabular}

Note: during the working day, the cook was entitled to lunch and break in the absence of orders on time.

Within this cyclogram an officer must make preparations in the absence of time mentioned above orders otherwise, but shifted slightly (up to a maximum of one hour). As a result, the application of the mission allowed motivating and controlling officer in the preparation of billets that has reduced temporary losses with $33.9 \%$ to $27.1 \%$ (around $7 \%$ ).

Comparing domestic and foreign experience in implementing lean production, it is possible to highlight the problem of introduction of lean production at the enterprises of the Russian Federation. One of the main problems is very important to understand what the enterprise wants to get from lean production, i.e. correctly prioritize. Moreover, on the basis of the allocated priorities must follow the systematization of lean production tools and the sequence of their use (table 3).

Table 3. Goals when implementing lean production

\begin{tabular}{|l|l|}
\hline Priority & \multicolumn{1}{|c|}{ Toolkit } \\
\hline Time & $\begin{array}{l}\text { Shortening order execution or } \\
\text { production (Just in time, Kanban, } \\
\text { Map the flow of value creation, } \\
\text { Visualisation, Standardisation, } \\
\text { Hejdzhunka, etc.) }\end{array}$ \\
\hline Staff & $\begin{array}{l}\text { Increased productivity (5S system, } \\
\text { Map the flow of value creation, } \\
\text { Visualisation, Standardisation, } \\
\text { Program improvements (SWIP), } \\
\text { etc.) }\end{array}$ \\
\hline Premises & $\begin{array}{l}\text { Optimal use of space (Map the } \\
\text { flow of value creation, Milk run, } \\
\text { Hejdzhunka, etc.) }\end{array}$ \\
\hline Equipment & $\begin{array}{l}\text { Improving the efficiency of the } \\
\text { equipment (Total Productive } \\
\text { Maintenance, Program } \\
\text { improvements (SWIP), SMED, } \\
\text { OEE or Overall Equipment }\end{array}$ \\
\hline
\end{tabular}




\begin{tabular}{|l|l|}
\hline & Efficiency, etc.) \\
\hline Cost price & $\begin{array}{l}\text { Cost reduction (Kaizen, FIFO } \\
\text { principle, Planning of material } \\
\text { requirements, MRP system, etc.) }\end{array}$ \\
\hline Defect & $\begin{array}{l}\text { Reducing the level of defect and } \\
\text { improvement of product quality } \\
\text { (Andon, Poka-yoka, Jidoka, etc.) }\end{array}$ \\
\hline
\end{tabular}

The introduction of a system of lean production in practice in Russia is often a disorderly and chaotic process, there is no common system of knowledge and set of methods and techniques. Currently a theoretical basis for lean production implementation has not yet been established. Therefore, it becomes necessary to study the successful experience of implementing lean production tools with a view to show the effectiveness of the application of lean production tools in different spheres of activity.

\section{Algorithm of applying of lean production tools}

To solve the above problem, author proposed the algorithm of introduction of lean production tools, which includes six main steps:

1. Identifying objectives and priorities;

2. Learning the basics and rules of lean production;

3. Identification of processes and activities that bring value to the consumer;

4. Finding «bottlenecks» in the work;

5. Identification of problems and tools for its decision;

6. Use tools and monitoring results.

The company «White Dragon» was used by the algorithm when correcting the «bottleneck» losses in preparation of blanks during the execution of the order. This algorithm is used cyclically for each process separately. For this process this algorithm has been successfully used and, as a result, it has reduced losses by 7 percent or 199 minutes.

\section{Conclusion}

By analyzing the results, it is possible to mention that lean does not have a single model of tools or practices and standards for services. It can be noticed that each author uses a «mix» of tools and practices that in their opinion best serves in an operation, this is, a collection of the best practices applied to specific needs of a company and its line of services.

Despite the lack of a standard set for which, when and where to use a lean tool in services, it can be seen that the best lean manufacturing practices, when applied to services, can generate large economic and financial results, as well as in the behaviour of people.

Summing up, it should be noted that ideas and lean production methods could play a significant role in the transformation of all branches of the Russian economy, in spite of the fact that lean production is a production tool initially, and helps to bring it to the level of the advanced developed countries, to enable businesses to survive in conditions of crisis providing conditions for further successful development.

\section{References}

1. J. Womack, D. Jones and D. Roos, The machine that changed the world (Popurri, 2014).

2. P. Dennis, Produção lean simplificada( Porto Alegre: Bookman, 2008).

3. J. Womack, D. Jones, Lean Thinking, Banish Waste and Create Wealth in Your Corporation (Free Press, 2003).

4. D. Bowen, W. Youngdahl, International Journal of Service Industry Management, 9(3), 207-225 (1998)

5. T. Levitt, Harvard Business Review, 50(5), 20-31 (1972)

6. E. Dyrina, Impuls-2013: proc. X Intern. scient. and practical conf. of students, young scientists and entrepreneurs in the field of economics, management and innovation (TPU, 2013)

7. N. Gavrikova, Problems of market economy management: interregional scientific papers, $\mathbf{1}$ (15), 16-18 (2014)

8. Higor dos Reis Leite, Guilherme Ernani Vieira, SciELO Brazil, 25 (3), 198 (2015) 